\title{
Identification of marker allergens in Brazilian soy allergic patients
}

\author{
Renata Cocco ${ }^{1 *}$, Dirceu Solé ${ }^{1}$, Marcia Mallozi ${ }^{1}$, Charles Naspitz ${ }^{1}$, Fredrik Bernhardsson², Sigrid Sjolander²,
} Maryam Poorafshar ${ }^{2}$, Anita Kober $^{2}$

From Food Allergy and Anaphylaxis Meeting 2011

Venice, Italy. 17-19 February 2011

\section{Background}

Soy allergy is established as one of the most common food allergies. Therefore, we decided to analyze whether there are specific protein markers among Brazilian soy allergic patients, using microarray techniques.

\section{Method}

Thirteen patients presenting with immediate symptoms after ingestion of soy formula and IgE reactivity to soy extract were selected after failing oral food challenges. Sixteen patients with no symptoms (negative soy challenge), but presenting with positive specific IgE to soy (ImmunoCAP $>0,35 \mathrm{kU} / \mathrm{L}$ ) were used as controls. In order to allow for simultaneous measurement of IgE responses, a number of purified proteins and protein mixes were used for analysis in a multiplexed capillaryflow based microarray assay.

\section{Results}

Significant differences between children with symptoms and without symptoms were found for $\beta$ conglycinin (Gly $\mathrm{m} 5$ ) and glycinin (Gly $\mathrm{m} 6$ ), the storage proteins of soybean. $\beta$-conglycinin showed higher response and glycinin, lower response by the tested patients.

\section{Conclusion}

The highest and most prevalent IgE reacitivity in the group of children with soy allergy was directed to the two storage proteins of soy, $\beta$-conglycinin and glycinin. Both proteins appear to be good marker allergens for soy allergy in Brazilian children.

\author{
Author details \\ ${ }^{1}$ Federal University of São Paulo, Pediatrics, São Paulo, Brazil. ${ }^{2}$ Phadia AB, \\ Uppsala, Sweden.
}

Published: 12 August 2011

doi:10.1186/2045-7022-1-S1-P72

Cite this article as: Cocco et al: Identification of marker allergens in Brazilian soy allergic patients. Clinical and Translational Allergy 20111 (Suppl 1):P72.
Submit your next manuscript to BioMed Central and take full advantage of:

- Convenient online submission

- Thorough peer review

- No space constraints or color figure charges

- Immediate publication on acceptance

- Inclusion in PubMed, CAS, Scopus and Google Scholar

- Research which is freely available for redistribution

Submit your manuscript at www.biomedcentral.com/submit
() Biomed Central
C Biomed Central 